\title{
Users of the Public Bathhouse of Alcântara: health profile diagnosis
}

\author{
Utilizadores do Balneário Público de Alcântara: diagnóstico da situação de saúde \\ Los usuarios del Baño Público de Alcântara: diagnóstico del estado de salud \\ Amélia Simões Figueiredo*; Ana Resende**; Cândida Ferrito***; \\ Isabel Rabiais****; Sílvia Caldeira*****
}

\begin{abstract}
Background: The community outreach project of the Universidade Católica Portuguesa, which involves the public bathhouse of Alcântara, started out of the need to identify its users.

Objectives: To characterize the users' socio-demographic and health profile and describe their use of social and health resources. Methodology: A cross-sectional descriptive study, of quantitative nature, was conducted with the application of a questionnaire to a sample of 145 participants.

Results: The typical user is male, single, aged 25-35 years and lives alone (21\%). This user goes to the public bathhouse two to three times per week. Most of the users (58.3\%) have no bathroom, $29.7 \%$ are homeless, $35.2 \%$ are not registered in any health care center, and 24.8\% have mental disorders.

Conclusion: The typical bathhouse user is of working age, was born in Lisbon and in the Portuguese-speaking African Countries, and has no source of income. The main reasons leading to the use of the public bathhouse are the economic difficulties, the homeless condition, and the lack of sanitary conditions.
\end{abstract}

Keywords: community health nursing; community intervention; vulnerable groups

\section{Resumo}

Enquadramento: O projeto de extensão à comunidade da Universidade Católica Portuguesa, que envolve o Balneário Público de Alcântara, iniciou-se com a necessidade de conhecer os seus utilizadores.

Objetivos: Caracterizar o perfil sociodemográfico e de saúde dos utilizadores e descrever a utilização dos recursos sociais e de saúde.

Metodologia: Estudo descritivo e transversal, de natureza quantitativa, com aplicação de formulário a 145 utilizadores.

Resultados: O utilizador típico é do sexo masculino, solteiro, vive só, tem entre 25 e 35 anos (21\%). Este utilizador frequenta o balneário, duas a três vezes por semana. A maioria (58,3\%) não tem casa de banho, 29,7\% são sem abrigo, 35,2 \% não estão inscritos em centro de saúde e 24,8\% têm patologia do foro mental.

Conclusão: $\mathrm{O}$ utilizador tipo do balneário situa-se na fase ativa, é natural de Lisboa e dos Países Africanos de Língua Oficial Portuguesa e não tem qualquer fonte de rendimento. Os motivos que levam à utilização do balneário são as dificuldades económicas, a condição de sem-abrigo e a falta de condições sanitárias.

Palavras-chave: enfermagem em saúde comunitária; intervenção comunitária; comunidades vulneráveis

\footnotetext{
* Ph.D., Assistant Professor, Universidade Católica Portuguesa, 1649-023, Lisboa, Portugal [simoesfigueiredo@ics.lisboa ucp.pt]. Contribution to the article: literature search, data collection, statistical treatment and analysis, data analys and discussion, approval of the final version of the article. Address for correspondence: Instituto de Ciências da Saúde, Universidade Católica Portuguesa, Campus da Palma de Cima, 1649-023, Lisboa, Portugal. **. MSc, Guest Lecturer, Universidade Católica Portuguesa, 1644-023, Lisboa, Portugal [anaresende@ics.lisboa.ucp.pt|. Contribution to the article: data collection, analysis and discussion,

Ph.D., Adjunct Profeessor, Polytechnic Institute of Setúbal, 2914503, Setúbal, Portugal [candida.ferrito@ess.ips.pt. Contribution to the artide: literature search, data collection, analysis and discussion, approval of the final version of the article. ****as Ph.D., Assistant, Universidade Católica Portuguesa, 1649-023, Lisboa, Portugal [raby@ics.lisboa.ucp.pt]. Contribution to the article: literature search, data collection, analysis and discussion. ucp.pt]. Contribution to the article: data collection, discussion, approval of the final version of the article
}

\section{Resumen}

Marco contextual: El proyecto de extensión a la comunidad, de Universidade Católica Portuguesa, incluyendo el Balneario Público de Alcântara, se inició con la planificación en salud y necesidad de conocer sus usuarios.

Objetivos: Caracterizar el perfil social-demográfico y de salud de los usuarios y describir la utilización de los recursos sociales y de salud.

Métodos: Estudio descriptivo y transversal, de naturaleza cuantitativa, con aplicación de formulario a 145 participantes.

Resultados: El usuario típico es varón, soltero y vive sólo, con 25 a 35 años (21\%). Esto frecuenta el balneario dos a tres veces por semana. La mayoría $(58,3 \%)$ no tiene cuarto de baño, $29,7 \%$ son personas sin hogar, $35,2 \%$ no están matriculados en centro de salud y 24,8\% tienen trastornos mentales.

Conclusión: El usuario típico del balneario es activo, de Lisboa y de Países Africanos de Lengua Oficial Portuguesa y no tiene rendimiento. Los principales motivos que llevan a la utilización del balneario son las dificultades económicas, la condición de persona sin hogar y la falta de condiciones de salubridad.

Palabras clave: enfermería de salud comunitaria; intervención comunitária; comunidades vulnerables

Received for publication: 05.01 .16

Accepted for publication: 30.04 .16 


\section{Introduction}

One of the strategic axes for the Health System in the Portuguese National Health Plan for 2011-2016 focuses on the promotion of "citizenship for a culture of health and well-being, of accomplishment of personal, family and community life projects" (Direção-Geral da Saúde [DGS], 2011, p. 2). Citizenship is considered to be the responsibility for the development of society, through actions such as public and political participation, with the purpose of generating well-being and health in all ages, locations and occasions. The plan also sets out the following strategies:

To promote a culture of citizenship, based on the development of initiatives targeted at the community or population groups, aimed at improving literacy, capacity-building, empowerment and participation, based on axes such as the dissemination of information, the development of skills, and the engagement and participation in individual, institutional and political decisions, while creating conditions for citizens to become more autonomous and responsible regarding their health and the health of those who depend on them, as well as promoting a positive view on health. (DGS, 2011, p. 14).

Within the scope of its mission, the Universidade Católica Portuguesa (UCP) aims at studying the problems of the Portuguese society and promoting cultural values through research. Therefore, this article reports on a study conducted with the purpose of describing the profile of the users of the Public Bathhouse (PB) of Alcântara and results from a community outreach project developed by the university. The PB is a bathhouse in Lisbon with free bathroom services that allows users to perform their personal hygiene, as well as to obtain clothing and bedding and wash their clothes. According to the regulations of the $\mathrm{PB}$, its services are reserved for city residents in a situation of deprivation and allow users to perform basic personal hygiene care (Regulamento do Balneário Público de Alcântara, n.d.).

The objectives of this study are to characterize the sociodemographic and health profile of $\mathrm{PB}$ users, and describe their use of social and health care resources.

\section{Background}

Public baths were used for several purposes in ancient times. From a more spiritual and religious perspective, they were seen as a way to purify the body and soul. The influence of ancient Greek culture also provided them with a sporty meaning. However, because they were a group activity, they had a social dimension which resulted from the influence of the Roman culture. Nowadays, the main purpose of public bathhouses is to improve and facilitate one of the most basic social rights of individuals: hygiene (Rebelo, 2013).

The Public Bathhouse of Alcântara is a municipal facility managed by the Parish Council and is an important resource among the 18 public bathhouses in the country's capital city. It was inaugurated in the 1930s, with the main purpose of providing support to the most deprived populations (Rebelo, 2013).

Bathing is a basic human need of major importance to the individuals' well-being, their relationship with others and themselves. Therefore, it is important to understand the conditions offered by society to those who are not able to satisfy this need. Given the nature of this community outreach project, we expect to draw the nurses' attention to these more vulnerable populations, with a view to future intervention. In this context, considering that bathing is an important activity of human dignity and that the maintenance of personal hygiene is required for comfort, protection and well-being (Kolcaba, 2009; Ribeiro \& Costa, 2012), nurses are in a privileged position in the relationship with the body of the person in a vulnerable situation by expressing the sense of health in daily life (Honoré, 2004). Bathing is an activity of private life which, in this situation, becomes part of the public life, even with the guarantee of privacy. A space which should be of the self becomes ours and even public and, from this perspective, it becomes not only a place where this physical need is met, but a place where users are faced with their living conditions, dignity and meaning of life (Baldacchino, 2010).

The characterization of the users of such a specific context as that of the $\mathrm{PB}$ is a key stage in the process of health planning, as well as the planning of a community outreach project, which aims to provide effective answers. Diagnosing is analyzing a given 
reality with a view to identifying needs and solutions (Imperatori \& Giraldes, 1993). In this context, and because health impacts the way people are capable of dealing with social and economic changes and the possibility of collective adjustment (Baldacchino, 2010), the main objective of this study, resulting from the development of the community outreach project, is to characterize the users of the Public Bathhouse of Alcântara (PBA). Additionally, it also aims to contribute to empower the $\mathrm{PB}$ users to better manage their health/disease processes, by developing endogenous strategies, to improve their ability to make decisions leading to health gains, and to stimulate networking between community resources, as social and health support providers.

\section{Research questions}

What is the socio-demographic and health profile of the PBA users? What are the social and health care resources used by the users?

\section{Methodology}

We conducted a descriptive cross-sectional study, with a quantitative approach. Before the implementation of the empirical phase, the principal investigator met with the President of the Parish Council, the person responsible for the $\mathrm{PB}$ and the people working at the $\mathrm{PB}$. It was possible to identify that the $\mathrm{PB}$ is attended by an average of 50 people per day, around 300 people per week, between 7.30 and 12 am, only closing on Mondays. Of these 300 users, some use the PB more than once a week. Data were collected through a questionnaire with closed-ended and mixed questions, for a period of 2 weeks, between Tuesday and Sunday, in July 2014. The pre-test included 10 users who were not part of the sample, in order to assess if the questions were easy to understand, if the response options were adequate and to determine the mean completion time. A non-probability sampling process was used which resulted in a convenience sample composed of 145 participants. The following inclusion criteria were established: being a user of the $\mathrm{PB}$ and being over 18 years of age. The users were invited to participate in the study at the PB. The researcher read the informed consent to each user who only became part of the study after his/her agreement to participate. Data were analyzed using descriptive statistics through the software Statistical Package for the Social Sciences (SPSS), version 17.0 for Windows.

The study was approved by the Ethics Committee for Health of the Regional Health Administration of Lisbon and the Tagus Valley and the Parish Council of Alcântara (Process PROC. 042/CES/INV/2014, 4-42014).

\section{Results}

\section{Demographic characterization}

Of the $145 \mathrm{~PB}$ users in the sample, most of them, 114 (78.6\%), are men. Of these, 96 (66.2\%) are single, 96 live alone (66.2\%), and 16 (11\%) cohabit. We found that 37 (25.5\%) users live in the parish of Alcântara and that the remaining users live in other Lisbon parishes (Figure 1).

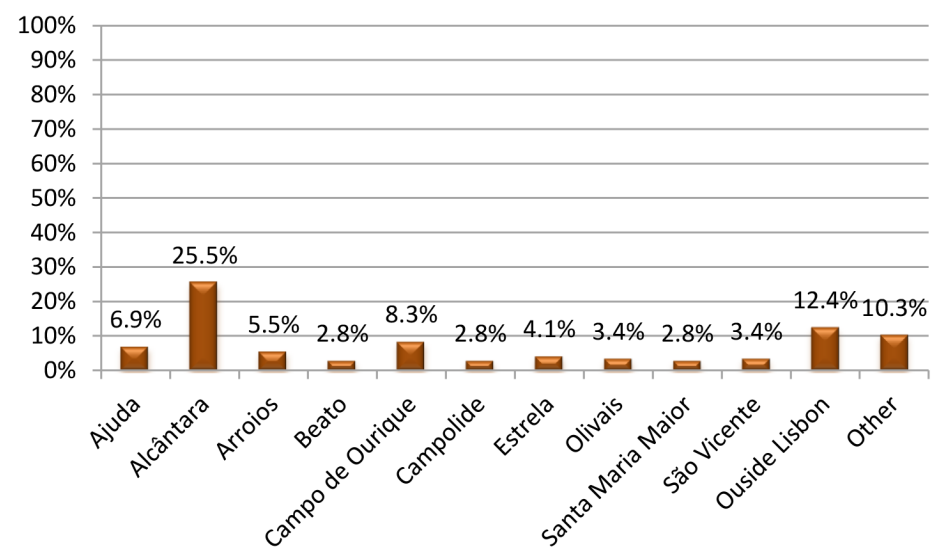

Figure 1. Distribution of the PB users according to their parish of residence. 
We highlight that 62 (42.8\%) PB users were born in Lisbon, 23 (15.9\%) in Portuguese-speaking African
Countries (PALOPs), and 18 (12.4\%) in the Northern region of Portugal (Figure 2).

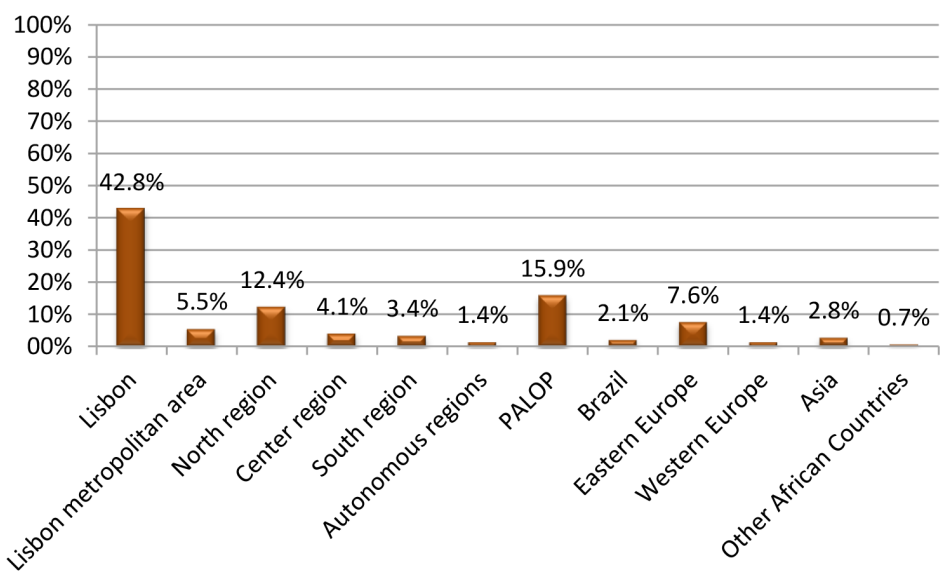

Figure 2. Distribution of the PB users according nationality.

Thirty-six users, which corresponds to $21 \%$ of the users, were aged between 25 and 35 years, followed by 27 (19\%) of them who were aged between 35 and 45 years, and 27 (19\%) who were aged between 45 and 55 years. In addition, 2\% of the users did not answer or did not know how old they were. Of the interviewed users, 18 (12\%) were older than 65 years. Most users are in the age range corresponding to the population in working age.

\section{Socio-economic characterization}

With regard to the source of income, 83 (57.2\%) users mentioned having no source of income; 20 (13.8\%) of them receive the Social Integration Income; 25 (17.2\%) receive their retirement benefits or a pension; and 12 (8.2\%) of them received a salary. In general, most (87\%) of the users received a monthly income lower than EUR 500.

We found that 63 (43.4\%) of the users lived in an apartment or a house, and 33 (22.8\%) lived in rented rooms or in a part of a house where they can use a room, kitchen and bathroom. We highlight the fact that $43(29.7 \%$ ) of the users were homeless (Figure 3).

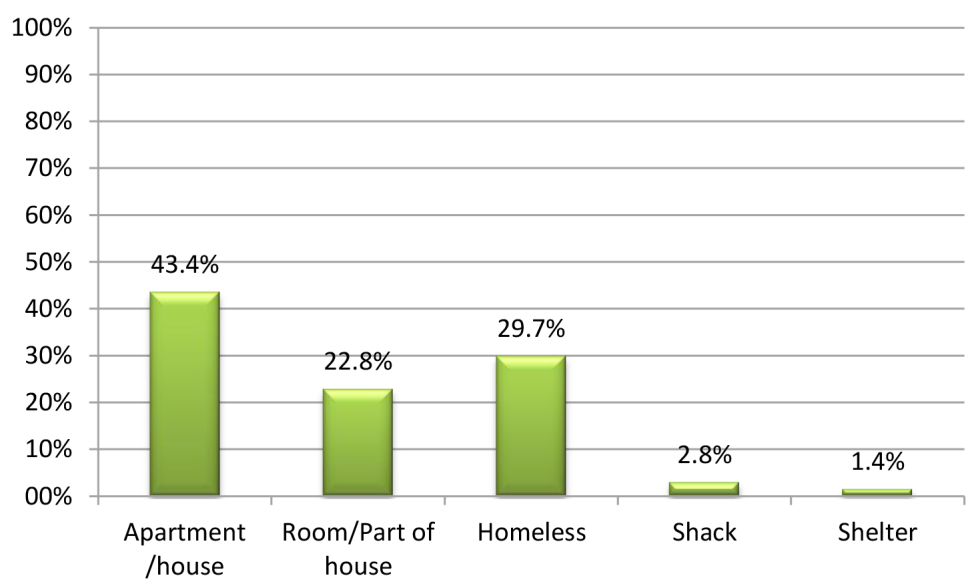

Figure 3. Distribution users according to the type of housing. 
Among the PB users, 56 (38.6\%) had no bathroom. Of the 71 (58.3\%) users who reported having a bathroom, 39 (26.9\%) had a shower, 32 (22.1\%) had a bathtub, and 15 (10.3\%) had no bathtub or shower. With regard to the frequency of use of the $\mathrm{PB}$, the majority, 62 (42.8\%) of the users used it two to three times per week; 28 (19.3\%) used it on a daily basis, and 28 (19.3\%) used it once a week.

As for the reasons why they used the PB, 60 (41.4\%) users mentioned economic reasons, 42 (29.7\%) mentioned that it was because they are homeless, 23 (15.9\%) reported that it was because they had degraded bathrooms, and 8 (5.5\%) of them said that it was because they could get clothes there.

\section{Use of health services by the participants}

With regard to the use of health services over the past 12 months, 57 (39.3\%) PB users had used them one to three times, 53 (36.6\%) had never used the health services, and 35 (24\%) have used them more than four times. Of those who used health services,
$40(27.6 \%)$ of them had attended a consultation with a family doctor, 33 (22.8\%) had used the emergency services, and 22 (15.2\%) had attended a consultation with a medical specialist. We found that 10 (6.9\%) users had attended a psychiatry consultation or had used treatment units for drug addiction.

We found that $51(35.2 \%)$ users were not enrolled in any cluster of health care centers. Most of the users were registered in the clusters of health care centers of Western Lisbon and Oeiras, 39 (26.9\%) and Central Lisbon, 33 (51\%), following the reconfiguration of the clusters of health care centers in accordance with Order no. 394-B/2012, of 29 November. Of the users registered in health care centers, 71 (49\%) of them had a family doctor and 74 (51\%) had no family doctor. In this sample, 57 (39.3\%) users mentioned having no diseases, 36 (24.8\%) reporting suffering from a mental disorder, 28 (19.3\%) mentioned having a cardiovascular disease, 12 (8.3\%) mentioned having HIV, and 11 (7.6\%) reported having Hepatitis B or C (Figure 4).

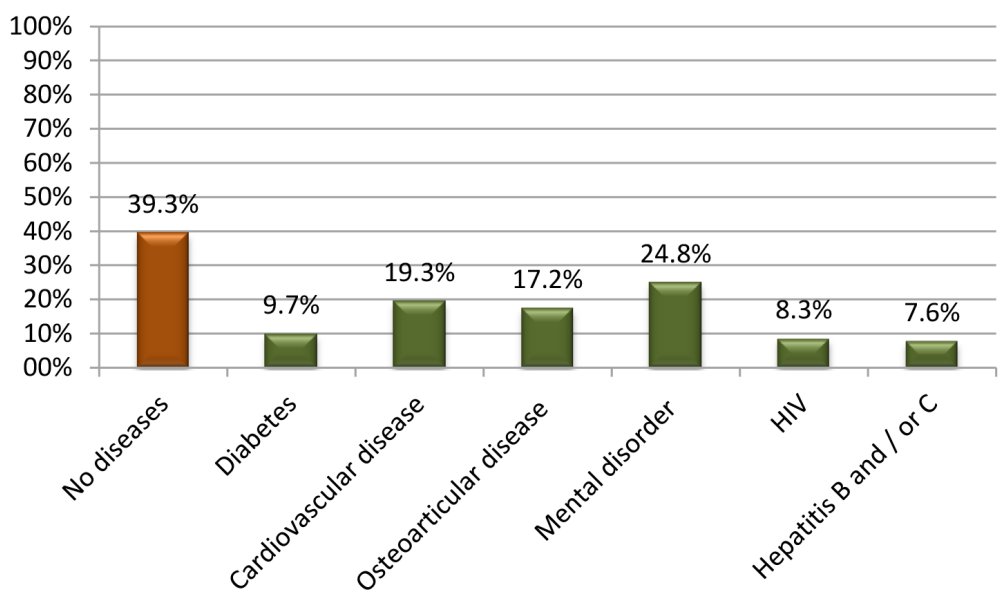

Figure 4. Distribution of the PB according to the presence or not of a disease.

\section{Discussion}

This study aimed to characterize the users of the PBA. Notwithstanding the priority assigned in health to translational research in vulnerable populations, the literature search conducted pointed to scarce scientific evidence on this issue.

We found that the participants' demographic characteristics are similar to those identified by Rebelo (2013), who found users to be predominantly male, single, and of working age. With regard to the socio-economic characterization, we found that 83 (57.2\%) users have no income. Comparatively, the unemployment rate among men in the parish of Alcântara was 12.71\% (Instituto Nacional de Estatística, 2012), with a tendency to increase even in societies with higher socioeconomic levels (Alves \& Rodrigues, 2010). Unemployment is a current determining factor among these participants that can promote the use of the $\mathrm{PB}$, since this community resource 
offers free services, such as bathing, clothing and laundry services. Unemployment is associated with higher rates of disease and early mortality (Alves \& Rodrigues, 2010). Thus, based on the unemployment rate among the male users and residents of the parish of Alcântara, we can conclude that this population is in a vulnerable situation, which may increase the risk for diseases.

In this study, the percentage of homeless people (29.7\%) was higher than the one found in the study of Rebelo (2013; 21.1\%). However, we found that other homeless people from other areas of Lisbon also used this $\mathrm{PB}$ on a regular basis. According to the report entitled Retrato da Saúde em Lisboa (Ministério da Saúde. Administração Regional de Saúde de Lisboa e Vale do Tejo IP, 2013), the homeless population is more likely of not having their health needs being met, in result of, for example, the lack of access to health services, funding problems, perception of low dignity and insufficient attention, due to the characteristics of marginality and rupture of social bonds.

From the epidemiological point of view, poverty is reflected in a low socio-economic level, deprivation, poor housing conditions and unemployment, among other aspects, and is a risk factor for disease in general and for mental disorders in particular (Alves \& Rodrigues, 2010). In addition, the access to health care is an important determining factor for the definition of the health condition.

The concept of social exclusion that emerged in the 1970s, and that would replace the term poverty in the 1990s, by the European Commission, emphasizes a number of aspects resulting from successive disruptions of the social bonds. Social exclusion would not be limited only to material deprivation, but, above all, it would point to desocialization and to an attachment crisis (Rego, 2014). A study carried out in the United Kingdom showed that feeling excluded, that there is no adequate response to their problems, and experiencing difficulties in the access to health care has a profound negative impact on the health and well-being of homeless people (Rae \& Rees, 2015). The reasons for using PBs are related to poor economic conditions.

The participants' daily use of the PB (19.3\%) is close to that found by Rebelo $(2013 ; 22.8 \%)$, where the author also found that most users were aged between 41 and 64 years, and that $60.7 \%$ of the participants used the PB because they were not able to pay for water and gas at home.
On the other hand, in a study developed in Japan, PBs are seen as a key social service for older people, in long-term care programs managed by nurses in public or home settings. The cultural values of the bath go beyond the dimension of hygiene care and comfort, since it is common for groups to attend thermal spaces to relax and the experience as a group is a way of being in life (Traphagariy, 2004).

We found that most participants did not use the health services in the past year and are not enrolled in any cluster of health care centers, and that about half of them have no family doctor. This is a central issue emphasized in this study, as it shows the way, within the scope of the community outreach project, to direct interventions or networking with existing community services. To this end, the law establishing the basis of health, Lei de Bases da Saúde, defines, in its general provisions, that "the Government promotes and ensures that all citizens have access to health care to the full range of the human, technical and financial resources available" (Lei no. 48, 1990, p. 3452).

The diseases mentioned by the participants fall within the national morbidity framework, although mental disorders are more prevalent. According to the Portuguese National Health Plan (DGS, 2011), based on the epidemiological data collected over the last decade, it is clear today that mental disorders and mental health-related problems have become the leading cause of disability and one of the leading causes of morbidity and premature death, especially in western industrialized countries. Attention should also be given to the cases of disease by viral infection. The human immunodeficiency virus (HIV) infection is internationally recognized as a threat to the social and economic development of the populations and has been considered as a priority in the Portuguese National Health Plan (DGS, 2011). Health decision-makers, communities, professionals and academics should join efforts to find strategies capable of promoting local development and social cohesion (Loureiro, Miranda, \& José, 2013; Jesus \& Menezes, 2010).

Taking into account the study objectives, the vulnerability of the population and the ethical aspects inherent to ensuring the respect for human dignity and intimacy, we decided to use the non-probability sampling process, resulting in a convenience sample, which we consider to be a limitation of this study. 


\section{Conclusion}

With regard to the demographic characterization, the typical user is male, single, of working age, lives in Alcântara, and is Portuguese. The sanitary and economic conditions, the loneliness and the condition of homeless seem to be the reasons for the current use of the PB. In relation to the socio-economic characterization, most PB users have no source of income, are in a situation of homelessness. As for their health status, most users did not perform health check-ups in the previous year and have no family doctor. They have comorbidities, namely mental disorders, and cardiovascular and contagious diseases.

Taking into account the social vulnerability and transcendence of the phenomena described in the results, the resources available in the University and in the Parish of Alcântara, we suggest the following community intervention priorities: mobilizing all the community resources that can help empower PB users for the proper management of their economic resources and promote their dignity; and establishing a nursing consultation with special focus on community mental health, by promoting the use of referral mechanisms for the more complex exclusion-related situations and the monitoring of specific needs associated with chronic diseases.

The health data emphasize that community intervention strategies should be implemented at this municipal facility aimed at the promotion and management of its users' health/disease processes. It is still necessary to reorganize the network of existing community health resources so as to maximize them. This should include the municipalities which, due to their close contact with the community are essential for the local strategy of implementing policies that promote better living and health conditions, as well as the capacity of these people to make decisions and face adversities.

\section{References}

Alves, A. A., \& Rodrigues, N. F. (2010). Determinantes sociais e económicos da Saúde Mental. Revista Portuguesa Saúde Pública, 28(2), 127-131.

Baldacchino, D. (2010). Spiritual care: Being in doing. Malta: Preca Library.
Direção Geral da Saúde (2011). Plano Nacional de Saúde 2011/2016. Retrieved from http://pns.dgs.pt/pns-2012-2016.

Honoré, B. (2004). Cuidar: Persistir em conjunto na existência. Loures, Portugal: Lusociência.

Imperatori, E., \& Giraldes, M. R. (1993). Metodologia do planeamento em saúde ( $3^{\mathrm{a}} \mathrm{ed}$.). Lisboa, Portugal: ENSP.

Instituto Nacional de Estatística. (2012). Censos 2011. Lisboa, Portugal: INE.

Jesus, M. F., \& Menezes I. (2010). A experiência de sem-abrigo como promotora do empoderamento sociológico. Análise Psicológica, 3, 527-35.

Kolcaba, K. (2009). Comfort. In S. J. Peterson, T. S. Bredow, Middle-range theories: Application to nursing research, (pp. 254-72). Philadelphia, USA: Wolters Kluwer/Lippincott Williams \& Wilkins.

Lei n. ${ }^{\circ}$ 48/90, de 24 de Agosto. Diário da República no 195/90 - I Série. Assembleia da República. Lisboa, Portugal.

Loureiro, I., Miranda, N. M., \& José, M. P. (2013). Promoção da saúde e desenvolvimento local em Portugal: Refletir para agir. Revista Portuguesa de Saúde Pública, 31(1), 23-31.

Ministério da Saúde. Administração Regional de Saúde de Lisboa e Vale do Tejo IP. (2013). Retrato da Saúde em Lisboa: Contributo para um Perfil de Saúde da Cidade. Lisboa, Portugal: ARS/LVT.

Portaria no 394 - B/2012 de 29 de novembro. Diário da República $n^{\circ}$ 231/12 - I Série. Ministério da Saúde. Lisboa, Portugal.

Rae, B. E., \& Rees, S. (2015). The perceptions of homeless people regarding their healthcare needs and experiences of receiving health care. Journal of Advanced Nursing, 71(9), $1-12$.

Rebelo, C. (2013). Balneários públicos de Lisboa expressão de garantia dos Direitos Sociais? (Dissertação de mestrado). Instituto Universitário de Lisboa, ISCTE, Lisboa, Portugal.

Rego, X. (2014). Entre a utopia e a crise nos meandros da (in) segurança urbana na segunda metade do século XX. Sociologia, Problemas e Práticas, 74, 93-110.

Regulamento do Balneário Público de Alcântara (s.d.). Livro de notas n. ${ }^{\circ}$ 182-A; p.89 Empreitada n. ${ }^{\circ}$ 108/55 - Obras de Beneficiação e limpeza dos balneários do Alto da Serafina e Alcântara. Arquivo Histórico Municipal do Arco Cego. (Unpublished document).

Ribeiro, P., \& Costa, M. (2012). O conforto do doente idoso crónico em contexto hospitalar: Contributos para uma revisão sistemática da literatura. Referência, 3(7), 149-58.

Traphagariy, J. W. (2004). Culture and long-term care: The bath as social service in Japan. Care Management Journals, 5(1), 53-60. 
